\title{
Surfer's Paradise: What the Law Says About Personal Internet Use During Working Hours
}

By Lars Schmidt and Andreas Maurer

Suggested Citation: Lars Schmidt and Andreas Maurer, Surfer's Paradise: What the Law Says About Personal Internet Use During Working Hours, 2 German Law Journal (2001), available at http://www.germanlawjournal.com/index.php?pageID=11\&artID=106

[1] A survey on Internet use by employees at their workstations published by Sterling Commerce on 29 August 2000 , showed that more than $60 \%$ of those employees that have access to the internet surf at least once a day for personal rather than their official business reasons. That means that every employee, on average, is online for about 3.2 hours each week - for personal reasons. This fact - according to the Sterling Report - causes a yearly loss for employers of about 104 Billion Deutsche Marks. In this calculation, costs for the connection to the Internet are not included.

General

Questions

[2] What does German labor law have to say with regard to this finding? Among the most important rules in German labor law, which is mostly derived from case law, involves the employer's right to give mandatory and binding instructions to his or her employees (Direktionsrecht des Arbeitgebers). Pursuant to this rule, the employer can supervise and inspect the employee's business email while at the same time prohibiting personal email at the employee's workstation. If the employee fails to comply with these instructions, he can be discharged after being warned. One question is, however, if such a warning or dissuasion can be legally superfluous in light of an interpretation of the law that strictly prohibits personal internet-surfing while at work. In the case that personal internet-surfing is permitted or tolerated by the employer, the employee has to respect the employer's interests by not exceeding a certain quantum of internet usage, appropriate and "usually" accepted by the employer.

Recent Case Related to Personal Internet-Surfing

[3] According to a recent decision by the Arbeitsgericht (Employment Court, First Instance) Wesel, the "usually" acceptable amount of personal internet usage is 80 to 100 hours per year. Surfing within this range does not justify a instant termination (fristlose Kuendigung) of the contract of employment. The contract at issue before the Employment Court contained no express provision relating to personal internet usage, so that - in the Court's holding - the permissibility of personal surfing needed to be assessed against both the background of the contract's silence on the matter and with regard to other factors (such as the employee's initial encounter with the internet for work reasons). In the Court's view, especially during a "playful training period" on the internet provided by the employer, personal internet-surfing

is permissible.(1)

Private

Emails

[4] In March, 2001, the Arbeitsgericht (Employment Court, First Instance) Frankfurt, ruled that an employee cannot be terminated without prior warning even if a general prohibition of sending personal emails had been issued in connection with the threat of instant dismissal in case of misconduct.(2) Here, the employee of a law firm sent a chain letter to her colleagues in the office. The Court found that a warning was still a necessary prerequisite to a legitimate dismissal. This would, however, not be the case, the Court held, if the employee's actions or statements clearly revealed that she will repeatedly break the contract or that she is no longer willing to meet contractual duties.(3) Prior warning before dismissal is also not necessary if the employee knowingly disrespects the employer's expectations, i.e., she knows that the employer in no case will accept her conduct. While it will often be difficult to assess such behavior, "clear" cases include insults, defamation and assault. However, the omnipresent and nearly overwhelming role of emails in daily life, ranging from spontaneous coffee-break arrangements to professional newsletters to the exchange of elaborate drafts of business or contract agreements, renders this legal evaluation (emails as a clear case of abuse of contract) considerably difficult. It is indisputable that email has, in innumerable ways, substituted other ways of instant communication in contemporary working life, such as telephoning. This fact necessarily makes any assessment of its role in the context of an employment contract a study in the measuring of degrees.

Private

Telephone

Calls

[5] Where intra-firm and external communication still involves a lot of telephoning, the same caution applies. The Landesarbeitsgericht (Regional Employment Court) Niedersachsen was confronted with a case of a secretary,(4) who made private telephone-calls up to 14 times a day. As a common practice in her company, private telephone calls were not generally prohibited. Moreover, with respect to overtime, the secretary asserted that private telephone calls had even been expressively permitted by the defendant employer. Nevertheless, after occurrence of her more than a dozen calls on a certain day, her contract was instantly terminated. The Court found this termination in violation to 
Section 1 para 2 of the Kuendigungsschutzgesetz (Federal Dismissal Protection Act). While holding that the disputed phone calls constituted a significant violation of contractual duties, and that - even under consideration of the employee generally being permitted to use the company's resources for private matters - this cannot be understood as granting her unlimited use of these resources, a contract's termination, in the Court's view, still requires a previous dissuasion in those cases where the employees conduct is controllable, because the relationship of trust, which is the basis of the employment contract,(5) can still be re-established.(6) Only in those cases where the relationship of trust between employer and employee is irrecoverably destroyed can the formality of a dissuasion can be dispensed with. This is especially the case when the breach of contract is obvious and evidently recognizable for the employee.(7)

General

Conclusions

[6] This field of law is in flux, especially in light of the continuously changing role of information technology in private and professional contexts. Still, the recent case law suggests a tendency toward the following basic principles:

(A) If the employer prohibits personal use of the company's resources, the personal use of the company's resources can justify the termination of the employment contract. However, a foregoing dissuasion is still necessary.

(B) If the employer permits the personal use of the company's resources, the admissibility of the contract's termination must be assessed in relationship to the amount and degree of explicit "personal" use of company resources. If it is considered to have been obvious for the employee that his conduct will in no case be covered by the employers consent, the termination is admissible. However, even in those cases a foregoing dissuasion may not be disposed with.. If the employee could not see that his or her conduct was inappropriate, the termination is usually not permissible.

(C) In German employment law related to the termination of a contract, a strong and decisive distinction is drawn between a termination based on personal qualities and pre-existing conditions of the employee him or herself ("Personenbedingte Kuendigung" [reasons can under certain circumstances be: lack of fitness for employment, lack of capacity, but also drug-addiction or alcoholism(8)]) and a termination based on the employee's inappropriate conduct ("Verhaltensbedingte Kuendigung" [reason for that can especially be any breach of employment contract, e.g. deterioration of employee's performance, tardiness or breach of employer's instructions.(9)]). In cases of termination based on personal qualities a dissuasion would certainly make no sense because it would have no influence on, e.g., an employee's permanent lack of capacity. The necessity of a dissuasion is designed to call the employees attention to his or her misconduct. Therefore, in cases of termination based on inappropriate conduct a dissuasion is normally necessary. This dissuasion is only dispensable, when the relationship of trust between employer and employee, being the essential basis of the employment contract, is irrecoverably destroyed. That is especially the case, when the inappropriate conduct is obvious and reasonably recognizable by the employee.

(1)See Arbeitsgericht Wesel, Decision of 21 March 2001, reg. no. 5 Ca 4021/00, published in: NEUE JURISTISCHE WOCHENSCHRIFT p.

2490.

(2)See Arbeitsgericht Frankfurt am Main, Decision of 20 March 2001, reg. no. 5 Ca 4459/00, available at http://www.jurpc.de/rechtspr/20010155.htm (last visited at 19 October 2001).

(3) See ERFURTER KOMMENTAR ZUM ARBEITSRECHT, Ascheid, Section 1 KUENDIGUNGSSCHUTZGESETZ (DISMISSAL PROTECTION ACT), $\quad$ Annotation 336.

(4) See Landesarbeitsgericht Niedersachsen, Decision of 13 January 1998, published in: NEUE ZEITSCHRIFT FUER ARBEITSRECHT- RECHTSPRECHUNGS $\quad$ REPORT $\quad 1998, \quad$ p. $\quad 259 \quad$ seq.

(5) If this trustful relationship is ruined the employer has the right to dismiss the employee instantly. (PalandtBuergerliches Gesetzbuch, 60th ed., section 626, annotation no.: 40; see also: Bundesarbeitsgericht (Federal Labor Court) decision of 12 August 1999, NEUE JURISTISCHE WOCHENSCHRIFT, p. 1069, 1971 (persistant jurisdiction).

(6) See Bundearbeitsgericht (Federal Labor Court), Decision of 04 June 1997; published in: NEUE ZEITSCHRIFT FUER ARBEITSRECHT 1997, p. 1281. This FLC decision is very remarkable as it constitutes a renunciation of a former persistant jurisdiction. In former jurisdiction a dissuation was not considered mandatory even if the trusful relationship could have been re-established.

(7) See Bundearbeitsgericht (Federal Labor Court), Decision of 10 February 1999, published in: NEUE 
ZEITSCHRIFT FUER ARBEITSRECHT 1999, p. 708 seq.; the rules laid out related to email and telephone usages at the work place also apply with regard to private photo copies, see, e.g. the Decision of 27 March 1980, Arbeitsgericht Berlin, reg. no. 12 Ca 3/80, published in: BETRIEBS BERATER 1980 , p.1105.

(8) See: Soergel-Kraft, preliminary remarks on section 620 German Civil Code (Beurgerliches Gesetzbuch), annotation no.:

89

et

seq.

(9) Soellner, Grundriss des Arbeitsrechts, 12th ed., 1998, p. 304. 